Hydrol. Earth Syst. Sci. Discuss., 3, 1315-1338, 2006 www.hydrol-earth-syst-sci-discuss.net/3/1315/2006/

(C) Author(s) 2006. This work is licensed under a Creative Commons License.
Hydrology and Earth System Sciences Discussions

Papers published in Hydrology and Earth System Sciences Discussions are under open-access review for the journal Hydrology and Earth System Sciences

\title{
Klinkenberg effect for gas permeability and its comparison to water permeability for porous sedimentary rocks
}

W. Tanikawa ${ }^{1}$ and T. Shimamoto ${ }^{2}$

${ }^{1}$ Kochi Institute for Core Sample Research, Japan Agency for Marine-Earth Science and Technology (JAMSTEC), 200 Monobe-otsu, Kochi, Japan.

${ }^{2}$ Department of Geology and Mineralogy, Faculty of Science, Kyoto University, Kitashirakawa-Oiwake-Cho, Sakyo-ku, Kyoto, Japan.

Received: 20 April 2006 - Accepted: 30 May 2006 - Published: 7 July 2006

Correspondence to: W. Tanikawa (tanikawa@jamstec.go.jp)

\section{HESSD}

3, 1315-1338, 2006

Klinkenberg effect for gas permeability measurement

W. Tanikawa and

T. Shimamoto

\section{Title Page}

Abstract Introduction

Conclusions References

Tables Figures

14 $\rightarrow$

4

Back

Close

Full Screen / Esc

Printer-friendly Version

Interactive Discussion 


\section{Abstract}

The difference between gas and water permeabilities is significant not only for solving gas-water two-phase flow problems, but also for quick measurements of permeability using gas as pore fluid. We have measured intrinsic permeability of sedimentary rocks 5 from the Western Foothills of Taiwan, using nitrogen gas and distilled water as pore fluids, during several effective-pressure cycling tests at room temperature. The observed difference in gas and water permeabilities has been analyzed in view of the Klinkenberg effect. This effect is due to slip flow of gas at pore walls which enhances gas flow when pore sizes are very small. Experimental results show (1) that gas permeability is larger than water permeability by several times to one order of magnitude, (2) that gas permeability increases with increasing pore pressure, and (3) that water permeability slightly increases with increasing pore-pressure gradient across the specimen. The results (1) and (2) can be explained by Klinkenberg effect quantitatively with an empirical power law for Klinkenberg constant. Thus water permeability can be estimated 15 from gas permeability. The Klinkenberg effect is important when permeability is lower than $10^{-18} \mathrm{~m}^{2}$ and at low differential pore pressures, and its correction is essential for estimating water permeability from the measurement of gas permeability. A simple Bingham-flow model of pore water can explain the overall trend of the result (3) above. More sophisticated models with a pore-size distribution and with realistic rheology of water film is needed to account for the observed deviation from Darcy's law.

\section{Introduction}

Permeability (or intrinsic permeability) is an important parameter to control the fluid flow systems at depths. Permeability would be wide ranges from $10^{-12}$ to less than $10^{-23} \mathrm{~m}^{2}$ for the various rock type and depth condition (i.e. Neuzil, 1994; Wang, 2000).

25 Several sedimentary rocks indicate strong anisotropy in permeability, and permeability is also sensitive to cracks and fractures. It is difficult to predict permeability from other

\section{HESSD}

3, 1315-1338, 2006

Klinkenberg effect for gas permeability measurement

W. Tanikawa and

T. Shimamoto

Title Page

Abstract Introduction

Conclusions

Tables

References

Figures

14

4

Back

Close

Full Screen / Esc

Printer-friendly Version

Interactive Discussion 
physical properties, such as porosity and grain size because of the complexity of the relationship. Permeability measurements under high confining pressure in a laboratory are a possible way to predict permeability structure at depths. One of the simple methods for the permeability measurement is steady state method, and using gas as

5 a pore fluid gives us the following advantages: (1) Commercial gas flow-meters that cover wide range of flow rate for any kind of gas is available so as to measure wide range of permeability quickly and accurately. (2) Nitrogen gas is chemically inert, and it is only necessary to consider the mechanical effects for the permeability changes with and increase of confining pressure. (3) Gas is less sensitive to temperature change 10 that may induce the error for permeability measurement compared to water.

Permeability does not depend on pore fluid, therefore permeability measured by gas should be the same with that measure by water. Therefore several fluid flow problems were analyzed using permeabilities that were measured by gas instead of water (Wibberley, 2003; Noda and Shimamoto, 2005; Wibberley and Shimamoto, 2005). However, 15 it has been argued that (1) permeability to gas changes with pore pressure changes at same effective pressure, and (2) permeability to gas is relatively higher than that to water. These problems might be related to the pore pressure dependence on gas permeability of Klinkenberg effect (Klinkenberg, 1941). There are few examples, though, that permeabilities are compared with different pore fluids for the same samples (Brace, et al.,1968; Faulkner and Rutter, 2000). Therefore, in this study, permeability measured by nitrogen gas as pore fluid is compared with that measured by water on same samples in effective pressure cycling tests. Then Klinkenberg effect for gas permeability is discussed from experimental data. Sedimentary rocks in the western foothills of Taiwan are used for permeability measurements.

\section{Intrinsic permeability and Klinkenberg effect}

Intrinsic permeability represents a mobility of fluid within porous rock materials and solely related to pore geometry of rocks itself (porosity, pore shape and pore size dis-

\section{HESSD}

3, 1315-1338, 2006

Klinkenberg effect for gas permeability measurement

W. Tanikawa and

T. Shimamoto

Title Page

Abstract

Introduction

Conclusions

Tables

References

Figures

14

4

Back

Full Screen / Esc

Printer-friendly Version

Interactive Discussion 
tribution etc.), and is independent of fluid property. Therefore, intrinsic permeability measured by any gas as pore fluid in a laboratory test should be same with that measured by any kinds of fluids. Permeability is functions of both medium and a fluid property, and its relationship to intrinsic permeability is given by

${ }_{5} K=\frac{k}{\eta} \rho g$

where $K$ is permeability (hydraulic conductivity) $(\mathrm{m} / \mathrm{s}), k$ is intrinsic permeability $\left(\mathrm{m}^{2}\right)$, $\eta$ is viscosity of fluid (Pa.s), $\rho$ is fluid density $\left(\mathrm{kg} / \mathrm{m}^{3}\right), g$ is gravitational acceleration $\left(\mathrm{m} / \mathrm{s}^{2}\right)$. Equation (1) indicates that fluid mobility depends on both fluid viscosity and density.

$10 \quad$ Klinkenberg (1941) discovered that permeability to gas is relatively higher than that to water, and he interpreted this phenomena as "slip flow" between gas molecules and solid walls. Gas molecules collide each other and to pore-walls during traveling through the pore medium. When the pore radius approaches to the mean free path of gas molecules, the frequency of collision between gas molecules and solid walls 15 increases. Therefore this additional flux due to the gas flow at the wall surface, which is called "slip flow", becomes effective to enhance the flow rate. This phenomenon is called Klinkenberg effect, and its effect is expressed as follows,

$$
\begin{aligned}
& k_{g}=k_{l}\left(1+\frac{4 c l}{r}\right)=k_{l}\left(1+\frac{c k}{\pi \sqrt{2} r^{3}} \frac{T}{p}\right)=k_{l}\left(1+\frac{b}{p}\right) \\
& b=\frac{c k}{\sqrt{2} \pi r^{3}}
\end{aligned}
$$

where $k_{g}$ is permeability to gas $\left(\mathrm{m}^{2}\right), k_{l}$ is permeability to liquid $\left(\mathrm{m}^{2}\right), /$ is mean free 20 path of the gas molecules $(\mathrm{m}), r$ is pore radius $(\mathrm{m}), k$ is Boltzmann's constant $\left(\mathrm{JK}^{-1}\right)$, $T$ is temperature $(K), c$ is constant, $p$ is pore pressure $(\mathrm{Pa}), b$ is Klinkenberg slip factor $(\mathrm{Pa})$. The third term in Eq. (2) is given by the following relationship,

$$
I=\frac{\kappa}{4 \pi \sqrt{2} r^{2}} \frac{T}{p}
$$

\section{HESSD}

$3,1315-1338,2006$

\section{Klinkenberg effect for gas permeability measurement}

W. Tanikawa and

T. Shimamoto

\section{Title Page}

Abstract Introduction

Conclusions

Tables

References

Figures

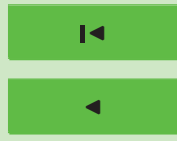

- I

Back

Close

Full Screen / Esc

Printer-friendly Version

Interactive Discussion 
(Furbish, 1997). Equation (2) indicates that if pore radius and gas pore pressure are small and temperature of gas is high, $k_{g}$ becomes much larger than $k_{l}$, and $k_{g}$ approaches to $k$, when pore pressure goes to infinite. Brace et al. (1968) and Zoback and Byerlee (1975) performed gas permeability tests at high pore pressure conditions $5 \quad(p=5$ to $15 \mathrm{MPa})$ by transient flow method as to avoid the Klinkenberg effect. Brace et al. (1968) showed that permeability to water on Westerly granite was similar to that to argon gas, however they did not suggest how large pore pressure is enough to avoid Klinkenberg effect for gas permeability tests.

Jones (1972) investigated the relationship between Klinkenberg slip factor $b$ and estimated water permeability $k_{\text {/ }}$ for about 100 core samples, and he found that the log $b$ was linearly increased with the log $k_{l}$ at the range from $10^{-12}$ to $10^{-17} \mathrm{~m}^{2}$. Persoff and Hulen (2001) estimated the relationship between $b$ and $k_{1}$ for less permeable metagraywacke $\left(10^{-18}\right.$ to $\left.10^{-22} \mathrm{~m}^{2}\right)$, and their results were generally consistent with Jones, though the slope seems steeper than Jones' line and their data are not enough 15 to convince the feature (8 points).

\section{Geological information for specimens}

Surface derived sandstones in the west-central part of the western foothills of Taiwan (Pleistocene to Miocene) were used for our permeability measurements (Table 1). The western foothills is known as a fold and thrust belt, which is developed by the Luzon 20 arc-Asian continental collision during Miocene (Lee, 1990). 1999 Taiwan Chi-Chi earthquake was occurred at the central part of this area, and one of the main thrust faults, the Chelungpu Fault is activated during the earthquake. The western foothills is also well known as oil and natural gas fields, and overpressure is observed at depths in the several oil wells (Suppe and Wittke, 1977). Therefore permeability at depth of fault 25 zones must act important roles for the earthquake behavior, and overpressure generation and maintenance must be related to permeability structure of the basin. Both water and gas permeabilities are also important parameters for oil and natural gas storage

HESSD

3, 1315-1338, 2006

Klinkenberg effect for gas permeability measurement

W. Tanikawa and

T. Shimamoto

Title Page

Abstract

Introduction

Conclusions

Tables

References

Figures

14

4

Back

Full Screen / Esc

Printer-friendly Version

Interactive Discussion

EGU 


\section{Experimental apparatus and permeability measurement}

All samples were cored and polished to cylindrical shapes. All specimens have lengths of 5 to $40 \mathrm{~mm}$ and diameters of approximately $20 \mathrm{~mm}$. Samples were dried at $80^{\circ} \mathrm{C}$ in 5 the oven to eliminate pore water for gas permeability measurement, without removing structured water adsorbed to clay mineral surfaces. The experiments were performed by an intra-vessel oil pressure apparatus at room temperature. Experimental system is described in Fig. 1 and the oil apparatus can be built confining pressure up to $400 \mathrm{MPa}$ by mini pressure generator. To confine pressure, avoid the leak, and eliminate the 10 lateral flow during permeability tests, samples are jacketed by 3 to 4 layers of polyolefin that can be easily contracted by heating.

To evaluate intrinsic permeability $k$, the linear form of Darcy's law is applied, and it is written as

$\frac{Q}{A}=\frac{k}{\eta L}\left(P_{\text {up }}-P_{\text {down }}\right)$

15 where $Q$ is the volume of fluid measured per unit time, $A$ is the cross-sectional area of the sample, $\eta$ is viscosity of the pore fluid, $L$ is sample length, and $P_{u p}$ and $P_{\text {down }}$ are pore pressure of the upper and lower ends of the specimen, respectively. Equation (3) can be applied to incompressible media, however when compressible gas ( $P V$ = constant) is used as pore fluid, the average gas permeability $k_{\text {gas }}$ is expressed as 20 (Scheidegger, 1974)

$\frac{Q}{A}=\frac{k_{\text {gas }}}{\eta L} \frac{\left(P_{\text {up }}\right)^{2}-\left(P_{\text {down }}\right)^{2}}{2 P_{\text {down }}}$.

Therefore Eq. (3) is used to calculate permeability to water and Eq. (4) for nitrogen gas in our experiment.
3, 1315-1338, 2006

\section{Klinkenberg effect for gas permeability measurement \\ W. Tanikawa and \\ T. Shimamoto}

\section{Title Page}

Abstract Introduction

Conclusions

14

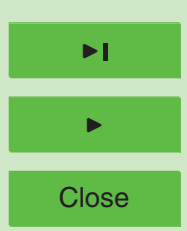

Back

Full Screen / Esc

Printer-friendly Version

Interactive Discussion

EGU 
Permeability was measured by the steady-state flow method that differential pore pressure, $P_{u p}-P_{\text {down }}$, is kept constant and that the flow rate flowing out from the downstream of the samples is monitored. Upstream side of pore pressure, $P_{u p}$, was controlled by the gas regulator for both gas and water permeability measurement, and

5 fluid that flows out from the downstream of a specimen was released to atmospheric pressure, which $P_{\text {down }}$ was assumed constant of $0.1 \mathrm{MPa}$. Viscosity of nitrogen gas and distilled water was assumed constant of $16.6 \times 10^{-6}$ (Pas) and, $1.0 \times 10^{-3}$ (Pas), respectively. Wide range of gas flow rate from 5 to $0.024 \mathrm{ml} / \mathrm{min}$, which corresponds to permeability from $10^{-13} \mathrm{~m}^{2}$ down to $10^{-19} \mathrm{~m}^{2}$ in our experiments, was easily measured 10 by coupling several gas flow meters. On the other hand, the flow rate of water was calculated using the digital balance to monitor the weight increment of water flowing out from specimen continuously. Therefore there is no lower limit for water permeability measurement if time permitted.

The confining pressure was cycled from $5 \mathrm{MPa}$ to the maximum $160 \mathrm{MPa}$ for perme15

ability tests. To compare permeability to nitrogen gas and that to water in the same specimen, nitrogen gas was used as a pore fluid for the first 2 or 3 pressure cycles, then distilled water was used instead of nitrogen gas for the last 2 pressure cycles. Before switching pore fluid from nitrogen gas to water, pore flow line was vacuumed for a while, then $\mathrm{CO}_{2}$ was filled in the pore flow line. After vacuumed again, water is 20 poured into the specimens. As solubility of $\mathrm{CO}_{2}$ to water is quite large under high pressure, we can minimize the influence of gas remained within pore and pore fluid lines for the water permeability measurement. Pore pressure dependence on permeability were also investigated to change the differential pore pressure at the same confining pressures.

\section{Experimental result}

The results of pressure cycling tests for sandstone specimens are shown in Fig. 2. As permeability varies significantly with the change of pore pressure, and error-bars in

\section{HESSD}

3, 1315-1338, 2006

Klinkenberg effect for gas permeability measurement

W. Tanikawa and

T. Shimamoto

Title Page

Abstract Introduction

Conclusions

Tables

References

Figures

14

4

Back

Full Screen / Esc

Printer-friendly Version

Interactive Discussion

EGU 
figures mainly represent the difference caused by the pore pressure variation (though pore pressure dependences were not measured in several points). The accuracy of flow rate is less than $1 \%$, therefore errors of each plot are within the symbols.

In IVA407, 5 cycles of the effective pressure test are conducted. For first three effec5 tive pressure cycle, nitrogen gas was used as a pore fluid, then distilled water was used for the other 2 pressure cycles. Permeability decreases with an increase of effective pressure in all pressure cycles, though the permeability reduces less than one order of magnitude even at $100 \mathrm{MPa}$. To compare the permeability at the same effective pressure and differential pore pressure (IVA407 in Fig. 2 plots permeability at $0.2 \mathrm{MPa}$ 10 of $\mathrm{P}_{\text {up }}-\mathrm{P}_{\text {down }}$ ), permeability to nitrogen gas is 2 to 4 times larger than that to water, and the permeability change due to pore fluid difference is largest compared to that due to change in effective pressure and its cycles at the same pore fluid. The other three specimens (IVA418, IVA419, and IVA478) showed similar trend with IVA407 that permeability to gas is larger than that to water at the same differential pore pressure. 15 However the ratio of permeability to nitrogen gas and water differs between samples. In the case of IVA419 that permeability is relatively smaller than IVA407, permeability to gas is 5 to 7 times larger than that to water. For IVA418 and IVA478 which permeabilities are lowest, permeability to gas is more than 10 times larger than that to water. These results imply that the permeability difference between nitrogen gas and water is larger for less permeable specimens.

Figure 3 illustrates the examples of the relationship between permeability to nitrogen gas and differential pore pressure. Generally, permeability decreases with an increase of differential pore pressure at all effective pressures. For IVA419, the maximum permeability difference among 0.2 to $0.8 \mathrm{MPa}$ of differential pore pressure is by the factor of 1.6 , and the difference is nearly the same with an increase of effective pressure.

Figure 4 describes the examples of the relationship between permeability to water and differential pore pressure. Permeability increases with an increase of differential pore pressure for IVA419, which indicates opposite trend to permeability to gas. The maximum difference in permeability due to the differential pressure change is by the

HESSD

3, 1315-1338, 2006

\section{Klinkenberg effect for gas permeability measurement}

W. Tanikawa and T. Shimamoto

Title Page

Abstract Introduction

Conclusions

Tables

References

Figures

14

4

Back

Full Screen / Esc

Printer-friendly Version

Interactive Discussion 
factor of 1.5. However, for IVA478, the differential pore pressure dependence on permeability is not clear.

HESSD

3, 1315-1338, 2006

\section{Discussion}

\subsection{Klinkenberg effect}

5 In Fig. 5, permeability to nitrogen gas is plotted against the inverse of the average pore pressure, $P_{a v},\left(P_{a v}=\left(P_{u p}+P_{\text {down }}\right) / 2\right)$ to confirm Klinkenberg effect. For most cases, permeability to gas increases linearly with an increase of $1 / P_{a v}$, and this is consistent with Klinkenberg equation on the assumption that average pore pressure is equivalent to pore pressure of $p$ on Eq. (2). Permeability to water $k$, can be estimated from these 10 slopes. Figure 6 shows the difference between estimated permeability from Klinkenberg equation and actual permeability to water. IVA478 indicates that both permeability is almost the same values. For IVA407, IVA418 and IVA419, estimated water permeability is smaller than actual ones, though the difference becomes much smaller compared to the difference between water and gas permeabilities, except IVA407. These 15 results suggest that difference of permeability between gas and water is strongly affected by Klinkenberg effect. For IVA407, estimated water permeability is disordered, and this might be caused by Turbulent flow at higher flow rate for permeability measurements.

\subsection{Klinkenberg slip factor}

20 Not only water permeability but Klinkenberg slip factor $b$ can be also approximated from the fitting slopes in Fig. 5. The relationship between water permeability and constant $b$, both of which are estimated from Eq. (2), for 30 sedimentary rocks at the western foothills (330 points) are plotted on Fig. 7 . Though the points are scattered, $b$ decreases with increasing permeability to water. The relationship in Fig. 7 is described

\section{Klinkenberg effect for gas permeability measurement \\ W. Tanikawa and \\ T. Shimamoto}

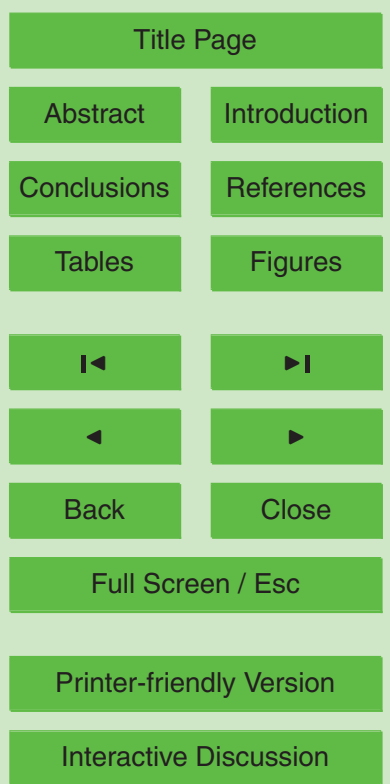


as,

$b=B \times k_{l}^{-C}$

where $B$ and $C$ are constants. When units of $k_{/}$and $b$ are selected as $\mathrm{m}^{2}$ and MPa respectively, the constants $B$ and $C$ are evaluated as $1.5 \pm 0.6 \times 10^{-7}$ and $0.37 \pm 0.038$, re5 spectively. The constant $C$ is consistent with previous study by Jones (1972) $(C=0.36)$. The constant $B$ becomes $7.0 \pm 0.4$ when $k_{l}$ and $b$ are expressed in the unit of md and psi, and the value is also consistent with Jones (1972) of $B=6.9$. However, under $10^{-19} \mathrm{~m}^{2}$ of permeability, the slope seems to become steeper, and this trend is consistent with Persoff and Hulen (2001).

If Eq. (5) is suitable to any sedimentary rocks, the relationship between the ratio of permeability to gas and water $k_{g} / k_{l}$ and differential pore pressure $P_{u p}-P_{\text {down }}$ in sedimentary rocks could be illustrated in Fig. 8. Constant $B=1.5 \times 10^{-7}$ and $C=0.37$, which were approximated from Fig. 7 , were applied. When permeability to water is higher than $10^{-16} \mathrm{~m}^{2}$, the ratio of permeability to gas and water is less than 2 . However 15 below $10^{-17} \mathrm{~m}^{2}$ of permeability to water, the gap becomes larger, and the ratio $k_{g} / k_{\text {I }}$ is 30 at $10^{-20} \mathrm{~m}^{2}$ of $k_{l}$ and $0.05 \mathrm{MPa}$ of differential pore pressure. Figure 7 implies we cannot neglect the difference between permeability to gas and water any more when permeability is small, and smaller differential pore pressure is applied for permeability measurements.

\subsection{Pore pressure dependence on water permeability}

As shown in Fig. 4, several specimens show differential pore pressure dependence on permeability to water. Sasaki et al. (2003) suggests this trend is due to Bingham plastic flow within small pores. Byerlee (1990) insisted that fluid that flows within the impermeable fault zone may act as Bingham flow, and this may increase the fluid pressure

\section{HESSD}

3, 1315-1338, 2006

Klinkenberg effect for gas permeability measurement

W. Tanikawa and

T. Shimamoto

Title Page

Abstract Introduction

Conclusions

Tables

References

Figures

14

4

Back

Close

Full Screen / Esc

Printer-friendly Version

Interactive Discussion a basis of Bingham flow formula for one capillary tube model is described as (Massey 
and Smith, 1998),

$Q=\pi \Delta p R^{4} /\left(8 L \mu_{p}\right) \times\left[1-(4 / 3)\left(\Delta p_{0} / \Delta p\right)+(1 / 3)\left(\Delta p_{0} / \Delta p\right)^{4}\right]$

HESSD

3, 1315-1338, 2006

where $R$ is radius of capillary tube $(\mathrm{m}), \Delta p_{0}$ is initial differential pressure that fluid flow occurs $(\mathrm{Pa}), \Delta p$ is differential pore pressure $(\mathrm{Pa}), L$ is a length of a flow path $(\mathrm{m}), \mu_{p}$ 5 is the slope of the relationship of shear stress against rate of shear when $\Delta p>\Delta p_{0}$ (Pa॰s). To combine Darcy's law in Eq. (1) with Eq. (6), permeability to Bingham plastic fluid is expressed as a following equation,

$k_{l}=\frac{Q \mu_{w} L}{A \Delta p}=R^{2} / 8 \times\left[1-(4 / 3)\left(\Delta p_{0} / \Delta p\right)+(1 / 3)\left(\Delta p_{0} / \Delta p\right)^{4}\right]$

where $\mu_{p}=\mu_{w}$ is assumed. The experimental result in IVA 389 is compared to Eq. (7) 10

which. all pore sizes are assumed to be same (Fig. 9). $\Delta p_{0}$ and $R$ that are evaluated by least square method became $0.047 \mathrm{MPa}$ and $0.049 \mu \mathrm{m}$, respectively. Approximation curve is generally consistent with experimental data that permeability increases with an increase of differential pore pressure, though Eq. (7) does not completely reproduce. This might be caused by the assumption that all pore sizes in the specimen are same, which are far from natural sedimentary rocks. Furthermore, approximated pore size of $0.049 \mu \mathrm{m}$ is quite large compared to general sandstone. Therefore accurate measurements of pore size distribution is necessary to discuss further. However, several data do not show the differential pore pressure dependence on water permeability clearly (Fig. 4), and to convince our assumption that Buckingham-Reiner equation is correlated to this positive pore pressure dependence, additional information such as porosity and grain size are also necessary.

Our laboratory experiments have focused on the porous sedimentary rocks, though it is questionable whether other rocks (incohesive rocks, granite, fractured rock etc.) show the same features. Faulkner and Rutter (2000) compared the permeability to 25 argon gas and that to water for clay rich fault rocks. Their data suggested that argon gas permeability is 10 times lager than that to water, which is in general consistent
Klinkenberg effect for gas permeability measurement

W. Tanikawa and T. Shimamoto

Title Page

Abstract Introduction

Conclusions

Tables

References

Figures

14

4

Back

Close

Full Screen / Esc

Printer-friendly Version

Interactive Discussion

EGU 
with our results. However they concluded the difference is caused by the reduction of effective pore diameter due to the adhesion of water molecules on crystal surface rather than Klinkenberg effect or the behavior of Bingham plastic flow. It is possible that several mechanisms might affect mutually for water and gas flow, and the most 5 dominant factor depends on the characteristics of specimens, such as the pore shape, mineral components and permeability.

\section{Conclusions}

Permeability was measured by nitrogen gas and water on the same specimens in effective pressure cycling tests, and followings are remarkable results in our study. 10 (1) Permeability to nitrogen gas was 2 to 10 times larger than that to water on the same specimen. (2) Permeability to nitrogen gas decreases with an increase of pore pressure (or differential pore pressure), and the relationship between permeability to gas and pore pressure could suit to Klinkenberg equation for most experimental data. Moreover water permeability estimate. (3) The relationship between Klinkenberg slip 15 factor $b$ and water permeability at the wide range from $10^{-14}$ to $10^{-20} \mathrm{~m}^{2}$ is consistent with the empirical relationship reported by Jones (1972) for permeable range $\left(10^{-12}\right.$ to $10^{-17} \mathrm{~m}^{2}$ ) that the log $b$ decreases linearly with an increase of log water permeability. (4) Permeability to water shows positive relationship to differential pore pressure, which can be partially explained by Buckingham - Reiner equation, though the approximation curve does not fully reproduce experimental data.

Our experimental results suggest that the difference between permeability to gas and water is explained by Klinkenberg effect. Therefore if the permeability measured by compressible gas is substituted for water permeability, it is preferable to revise gas permeability using Klinkenberg equation. Moreover it is better to include pore pressure avoid Klinkenberg effect during steady state gas permeability measurements, large differential pore pressure above $1 \mathrm{MPa}$ should be applied, though its value is not enough

HESSD

3, 1315-1338, 2006

Klinkenberg effect for gas permeability measurement

W. Tanikawa and T. Shimamoto

Title Page

Abstract Introduction

Conclusions

Tables

References

Figures

14

4

Back

Full Screen / Esc

Printer-friendly Version

Interactive Discussion

EGU 


\section{References}

3, 1315-1338, 2006

Brace, W. F., Walsh, J.B., and Frangos, W. T.: Permeability of granite under high pressure, J. Geophys. Res., 73, 2225-2236, 1968.

5 Byerlee, J.: Friction, overpressure and fault normal compression, Geophys. Res. Lett., 17, 2109-2112, 1990.

Faulkner, D. R. and Rutter, E. H.: Comparisons of water and argon permeability in natural claybearing fault gouge under high pressure at 20 degrees C: J. Geophys. Res., 105, 1641516 426, 2000.

Furbish, D. J.: Fluid physics in geology; an introduction to fluid motions on earth's surface and within its crust, Oxford university press, New York, 1997.

Jones, S. C.: A rapid accurate unsteady - state Klinkenberg parameter, SPE Journal, 383-397, 1972.

Klinkenberg, L. J.: The permeability of Porous media to liquids and gases, American Petroleum Institute, Drilling and Productions Practices, 200-213, 1941.

Massey, B. and Smith, J. W.: Mechanics of fluid, Spon press, London and New York, 1997.

Noda, H. and Shimamoto, T.: Thermal pressurization and slip-weakening distance of a fault; an example of the Hanaore Fault, southwest Japan., Bulletin of the Seismological Society of America, 95, 1224-1233, 2005.

Persoff, P. and Hulen, J. B.: Hydrologic characterization of reservoir metagraywacke from shallow and deep levels of The Geysers vapor-dominated geothermal system, California, USA, Geothermics, 30, 169-192, 2001.

Sasaki, T., Watanabe, K., Lin, W., and Hosoya, S.: A study on hydraulic conductivity for Neogene sedimentary rocks under low hydraulic gradient condition, Shigen-to-Sozai, 119, 587$25592,2003$.

Scheidegger, A. E.: The physics of flow through porous media, 3rd Edition. University of Toronto Press, Toronto, 1974.

Suppe, J. and Wittke, J. H.: Abnormal pore-fluid pressures in relation to stratigraphy and structure in the active fold-and-thrust belt of northwestern Taiwan, Petroleum Geology of Taiwan, 14, 11-24, 1977.

\section{Klinkenberg effect for gas permeability measurement}

W. Tanikawa and

T. Shimamoto

\section{Title Page}

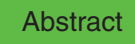

Introduction

Conclusions

Tables

References

Figures

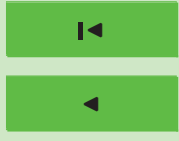

$>$ I

Back

Close

Full Screen / Esc

Printer-friendly Version

Interactive Discussion 
Teng, L. S.: Geotectonic evolution of late Cenozoic arc-continent collision in Taiwan, Tectonophysics, 183, 57-76, 1990.

Tsutsumi, A., Hirose, T., Mizoguchi, K., Uehara, S., Sato, K., and Shimamoto, T.: Measurement of Gas-permeability of rocks using an oscillating pore pressure method and a gas flow 5 method - an example of the Kakegawa Group siltstone, Shigen-to-Sozai, 119, 514-518, 2003.

Wibberley, C.: Hydraulic diffusivity of fault gouge zones and implications for thermal pressurization during seismic slip, Earth, Planets and Space, 54, 1153-1171, 2002.

Wibberley, C. and Shimamoto, T.: Earthquake slip weakening and asperities explained by thermal pressurization, Nature, 436, 7051, 689-692, 2005.

Zoback, D. M. and Byerlee, D. J.: The effect of microcrack dilatancy on the permeability of westerly granite, J. Geophys. Res., 80, 752-755, 1975.

\section{HESSD}

3, 1315-1338, 2006

Klinkenberg effect for gas permeability measurement

W. Tanikawa and

T. Shimamoto

Title Page

Abstract Introduction

Conclusions References

Tables Figures
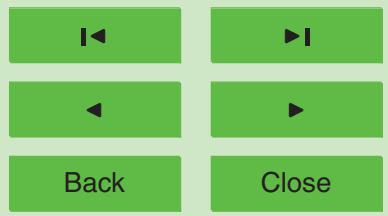

Full Screen / Esc

Printer-friendly Version 


\section{HESSD}

3, 1315-1338, 2006

Klinkenberg effect for gas permeability measurement

W. Tanikawa and

T. Shimamoto

Table 1. General information for specimens.

\begin{tabular}{lcccccc}
\hline Specimen symbo & Formation & $\begin{array}{c}\text { Burial depth } \\
(\mathrm{m})\end{array}$ & $\begin{array}{c}\text { Age } \\
(\mathrm{Ma})\end{array}$ & $\begin{array}{c}\text { Length } \\
(\mathrm{mm})\end{array}$ & $\begin{array}{c}\text { Diameter } \\
(\mathrm{mm})\end{array}$ & $\begin{array}{c}\text { Initial } \\
\text { porosity } \\
(\%)\end{array}$ \\
\hline IVA407 & Tungkeng Fm & $3900-4500$ & $11.6-14.5$ & 20.8 & 20.6 & 22.7 \\
IVA418 (IVA389) & Shihmentsum Fm & $4500-4800$ & $17.8-19$ & 12.4 & 20.7 & 13.6 \\
IVA419 & Kuanyinshan Ss & $4500-4800$ & $14-15$ & 23.4 & 20.3 & 20.6 \\
IVA478 & Hourdonqkeng Fm & $3900-4500$ & $13.9-18$ & 18.4 & 20.7 & 8.5 \\
\hline
\end{tabular}

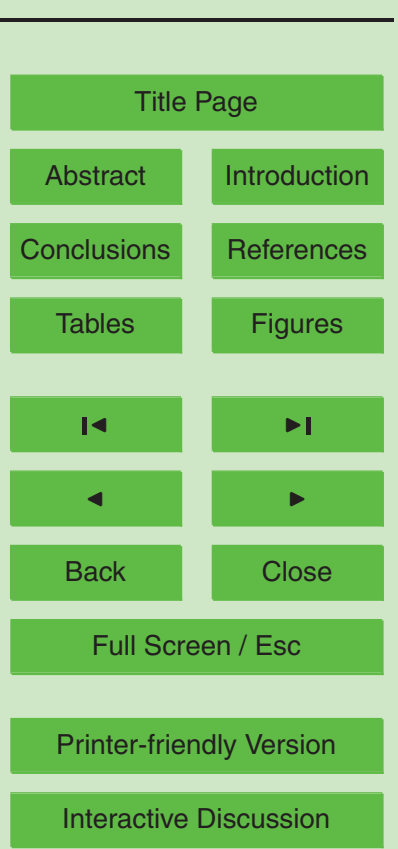




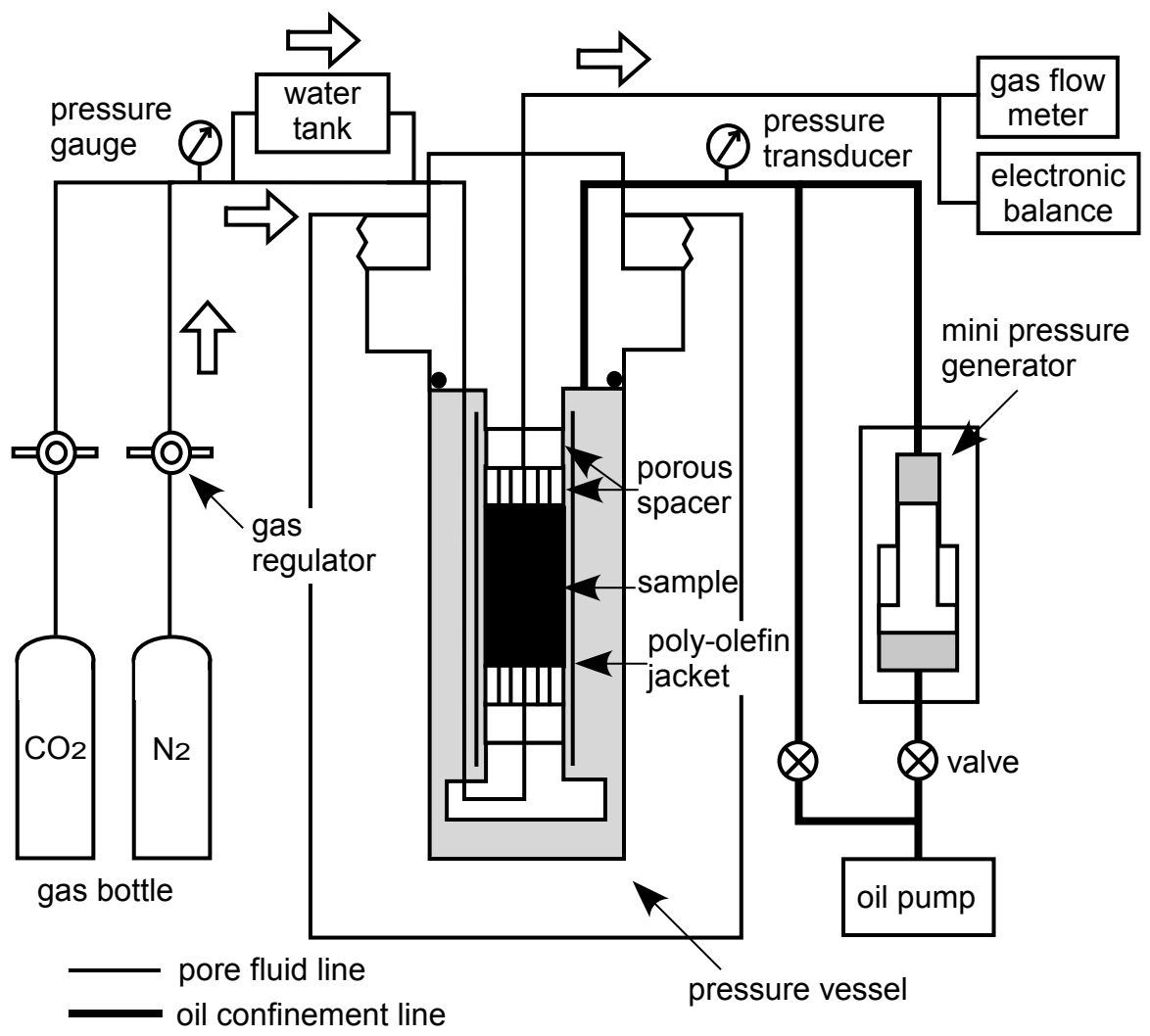

Fig. 1. Schematic diagram of gas/water permeability measurement system at high confining pressure.

\section{HESSD}

3, 1315-1338, 2006

Klinkenberg effect for gas permeability measurement

W. Tanikawa and

T. Shimamoto

Title Page

Abstract

Introduction

Conclusions

References

Tables

Figures

14

$\rightarrow$

4

Back

Close

Full Screen / Esc

Printer-friendly Version

Interactive Discussion 

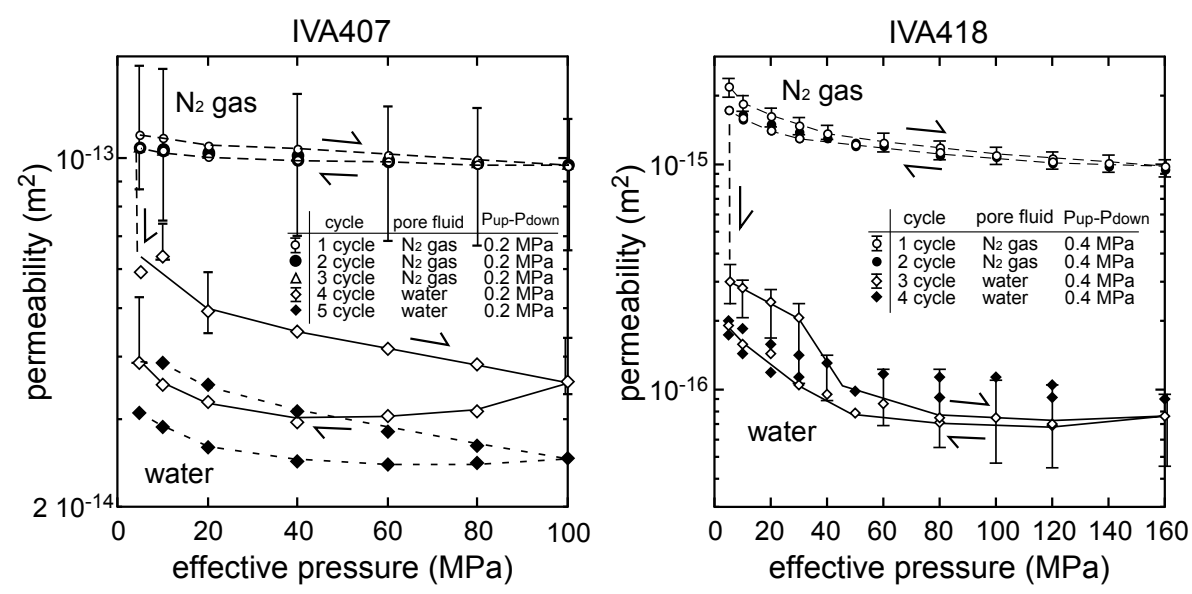

HESSD

3, 1315-1338, 2006

Klinkenberg effect for gas permeability measurement

W. Tanikawa and

T. Shimamoto
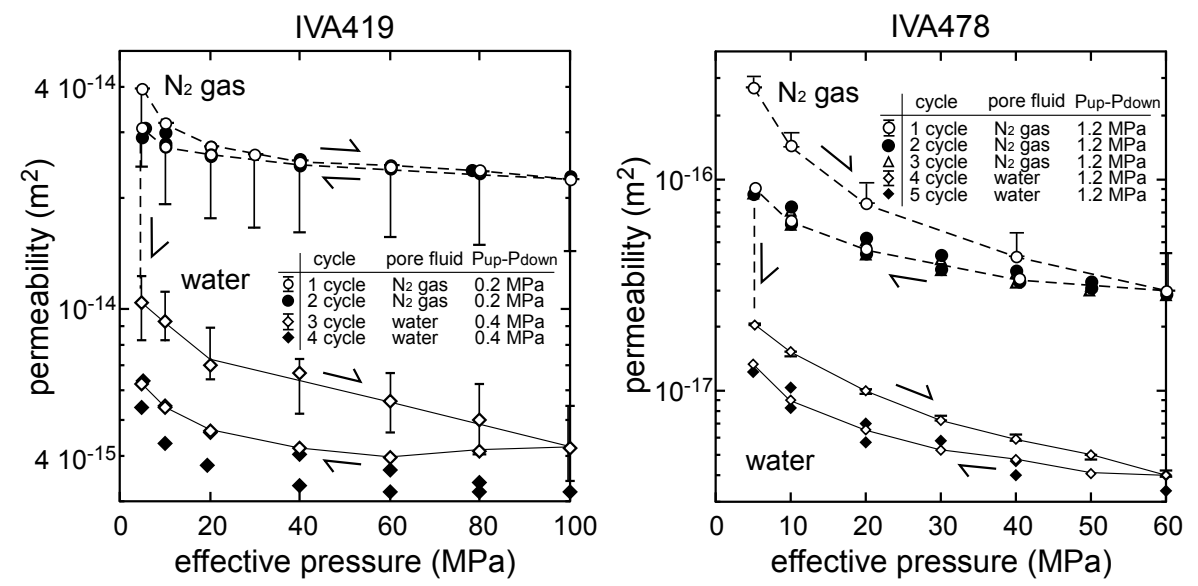

Title Page

Abstract

Introduction

Conclusions

References

Tables

Figures

14

4

Back

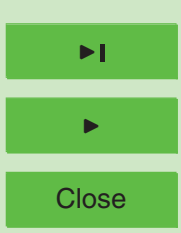

Full Screen / Esc

Fig. 2. Relationship between permeability and effective pressure in pressure cycling tests.

Printer-friendly Version Nitrogen gas was used as pore fluid in first 2 or 3 pressure cycles, then distilled water was used last 2 pressure cycles. Error bars mainly reflect on the pore pressure dependence on

Interactive Discussion permeability. 


\section{HESSD}

3, 1315-1338, 2006

Klinkenberg effect for gas permeability measurement

W. Tanikawa and

T. Shimamoto
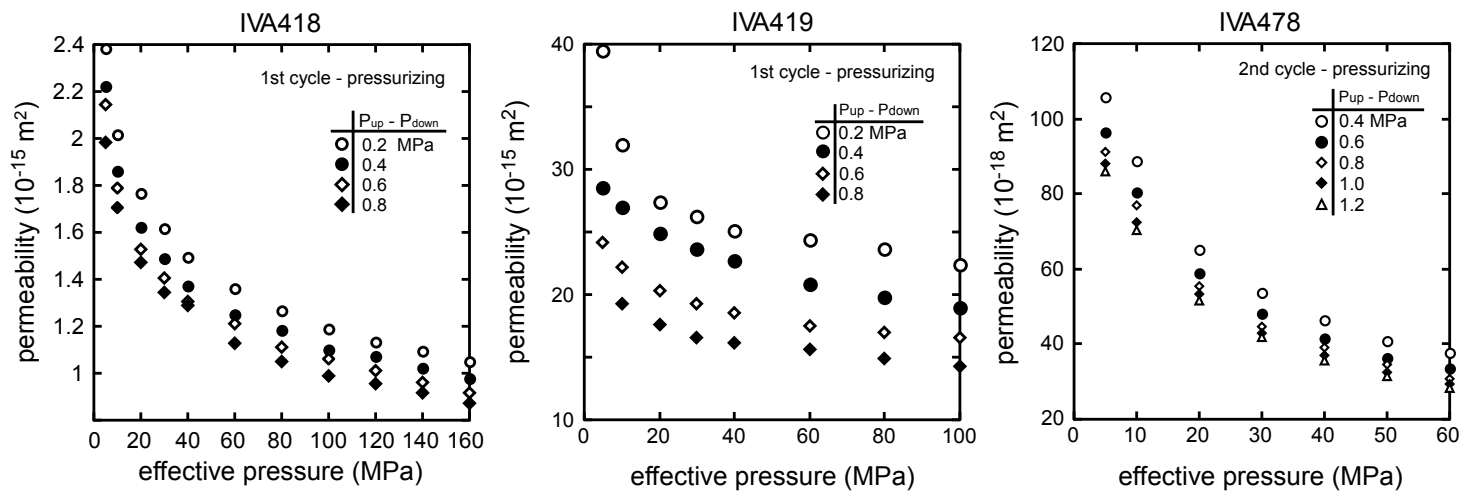

Fig. 3. Differential pore pressure dependence on permeability to nitrogen gas.
Title Page

Abstract Introduction

Conclusions

References

Tables

Figures

14

$>$ I

4

Back

Close

Full Screen / Esc

Printer-friendly Version

Interactive Discussion 


\section{HESSD}

3, 1315-1338, 2006

Klinkenberg effect for gas permeability measurement

W. Tanikawa and

T. Shimamoto

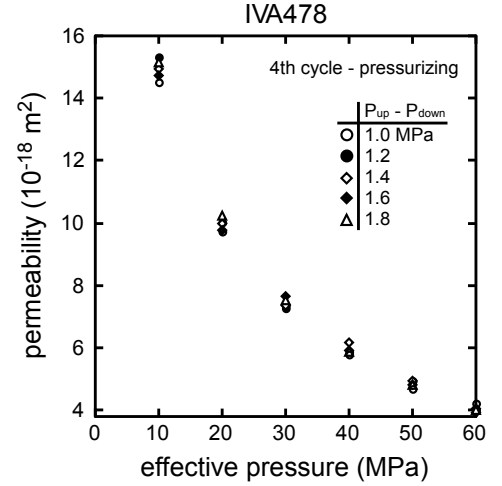

Title Page

Abstract

Introduction

Conclusions

References

Tables

Figures

14

$\rightarrow 1$

4

Back

Close

Full Screen / Esc

Printer-friendly Version

Interactive Discussion 


\section{HESSD}

3, 1315-1338, 2006

Klinkenberg effect for gas permeability measurement

W. Tanikawa and

T. Shimamoto

Title Page

Abstract

Introduction

Conclusions

References

Tables

Figures

14

$>$ I

Fig. 5. Relationship between gas permeability and inverse of average pore pressure to confirm Klinkenberg effect in Eq. (2).

\section{4}

Back

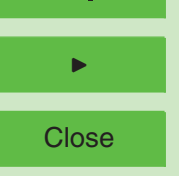

Full Screen / Esc

Printer-friendly Version 

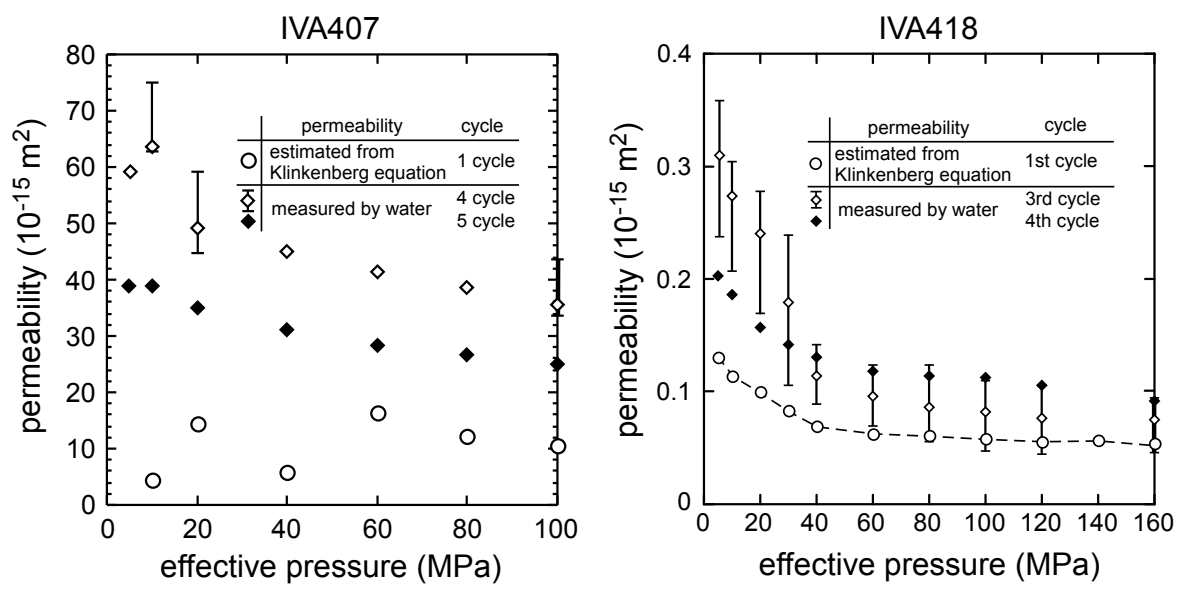

HESSD

\section{3, 1315-1338, 2006}

Klinkenberg effect for gas permeability measurement

W. Tanikawa and

T. Shimamoto
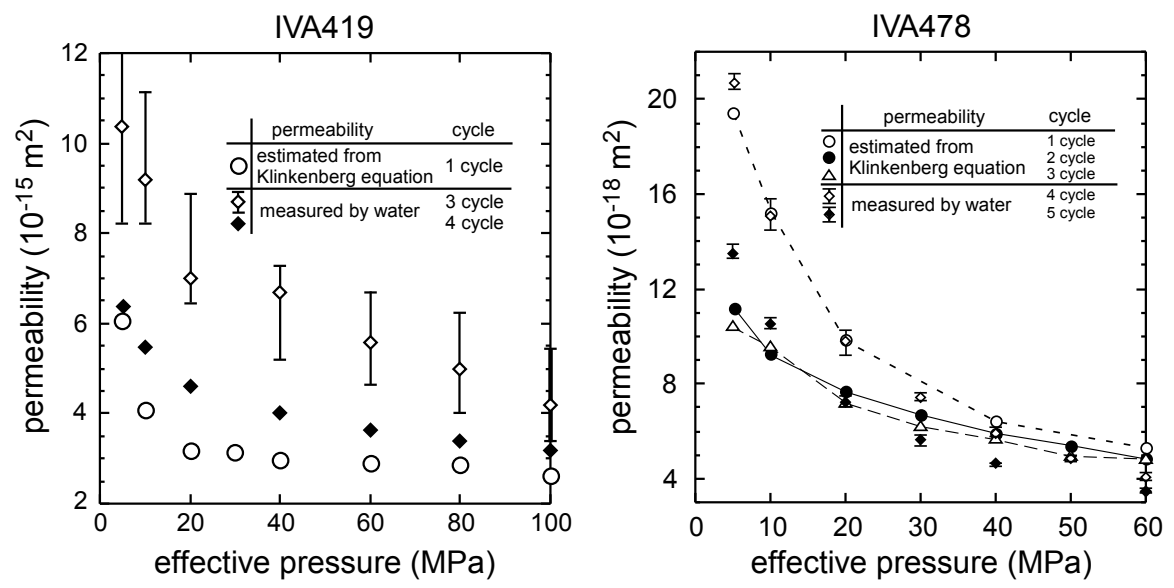

Title Page

Abstract

Introduction

Conclusions

References

Tables

Figures

14

- I

4

Back

Close

Full Screen / Esc

Printer-friendly Version

Fig. 6. Comparison of estimated water permeability from Klinkenberg equation and experimental data.

Interactive Discussion 


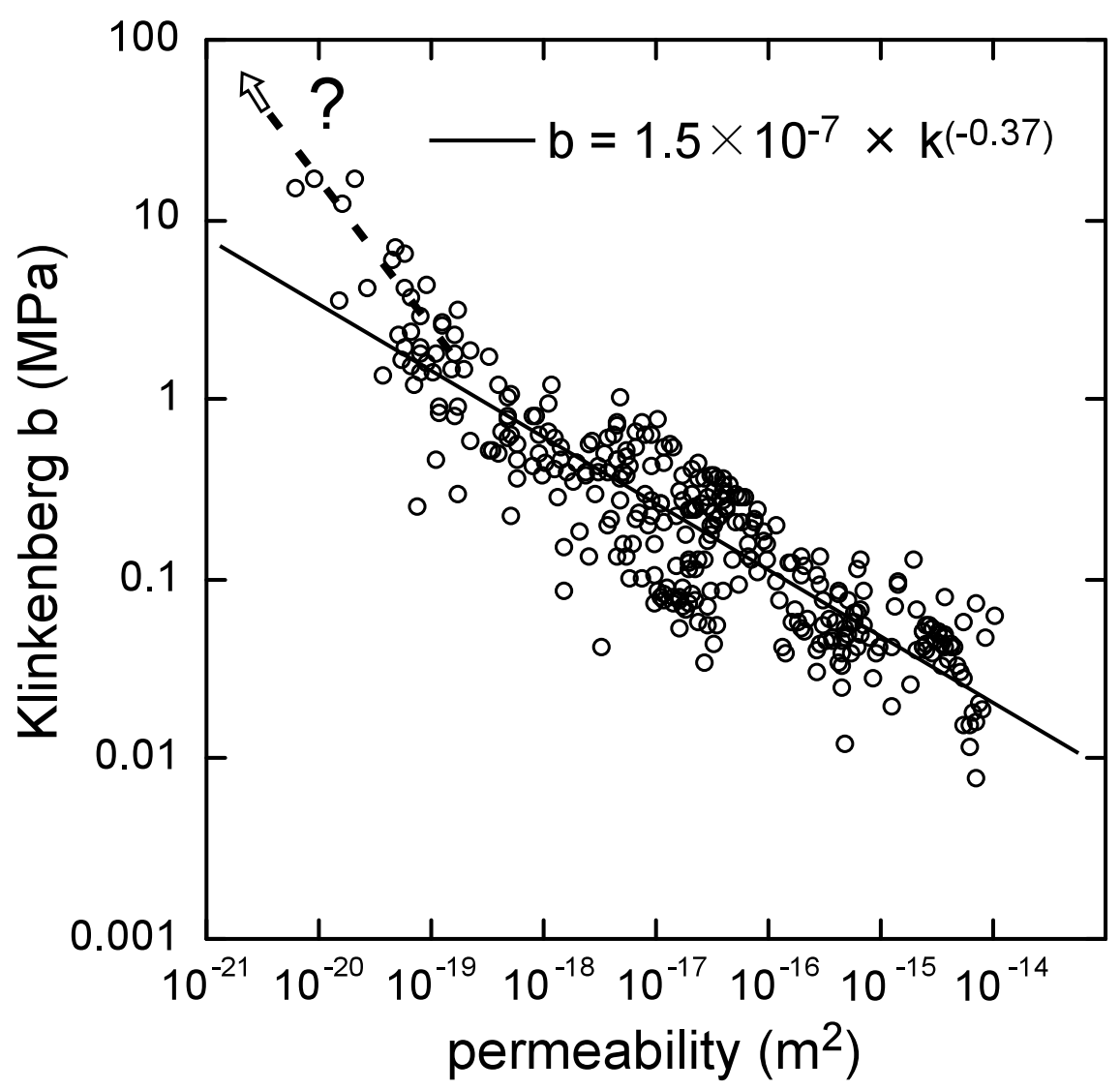

Fig. 7. Klinkenberg slip factor and estimated water permeability power law relationship from the result of gas permeability test for 30 sedimentary rocks in the Western Foothills.

\section{HESSD}

3, 1315-1338, 2006

Klinkenberg effect for gas permeability measurement

W. Tanikawa and

T. Shimamoto

Title Page

Abstract

Introduction

Conclusions

References

Tables

Figures

14

DI

4

Back

Close 


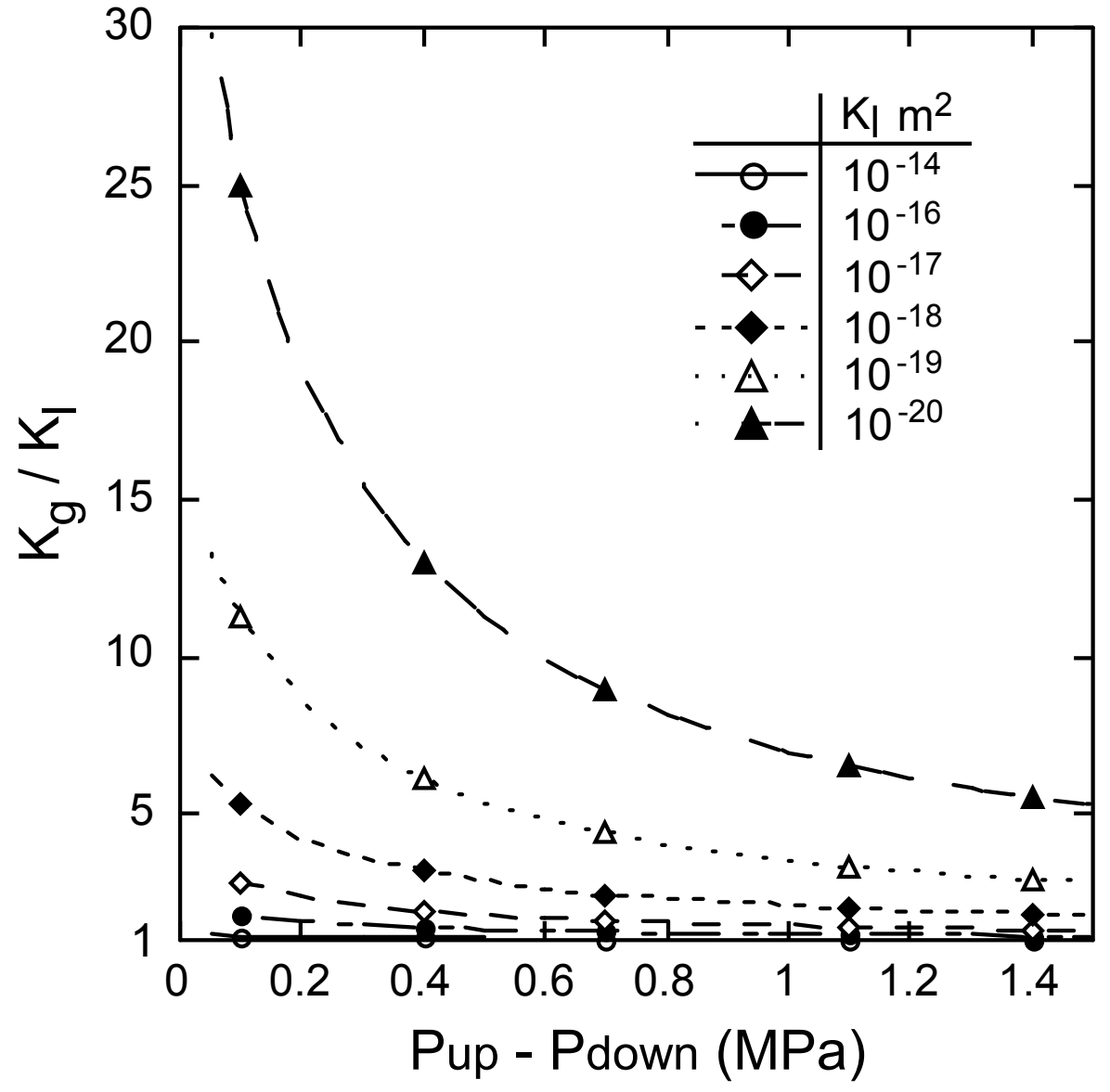

Fig. 8. The relationship between the ratio of gas and water permeability and differential pore pressure evaluated from the empirical relationship of Fig. 8. Constant $B$ of $1.5 \times 10^{-7}$ and $C$ of 0.37 are used to illustrate curves.

\section{HESSD}

3, 1315-1338, 2006

Klinkenberg effect for gas permeability measurement

W. Tanikawa and

T. Shimamoto

Title Page

Abstract

Introduction

Conclusions

References

Tables

Figures

14

$\rightarrow$

4

Back

Close

Printer-friendly Version

Interactive Discussion 


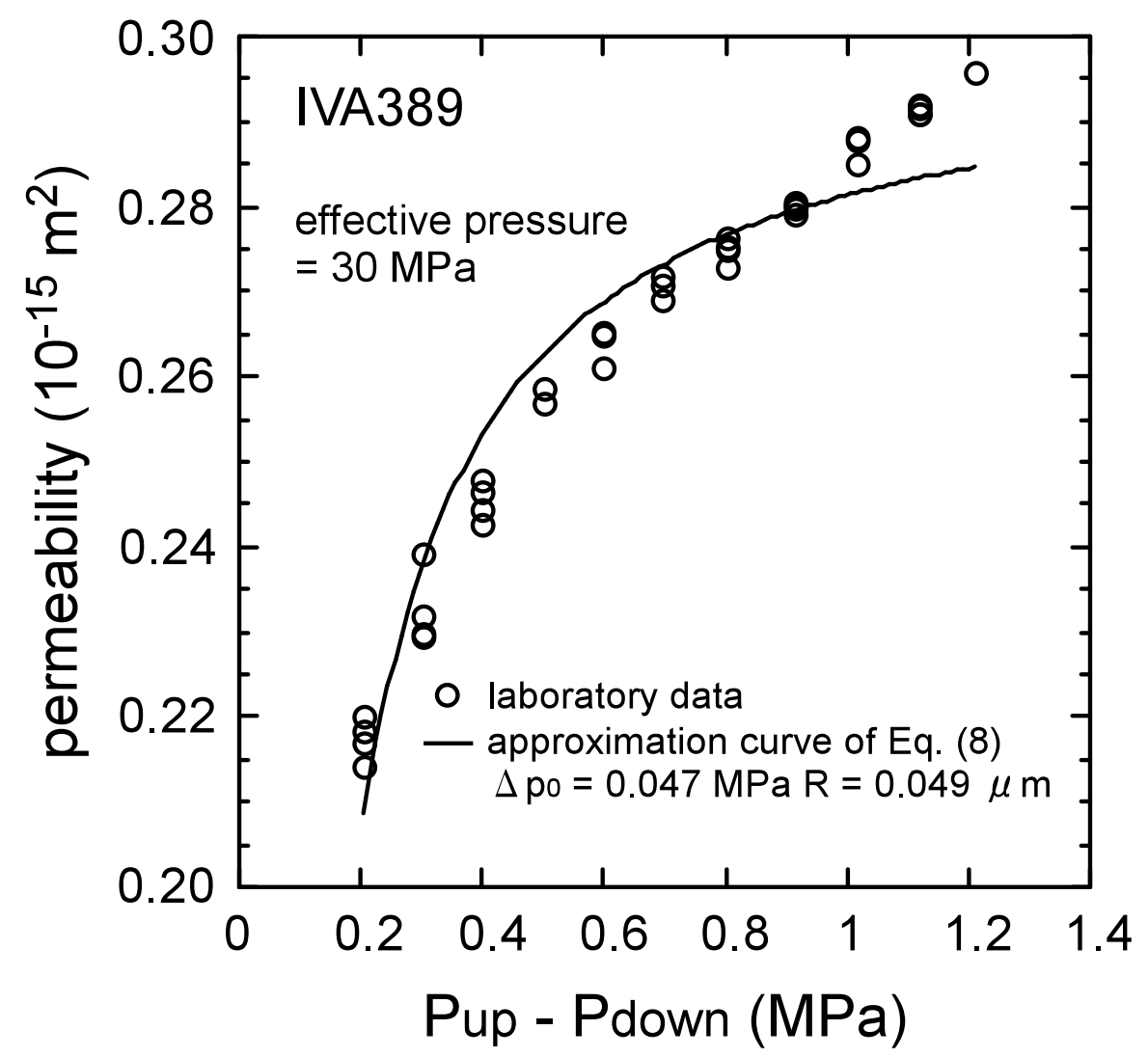

Fig. 9. Differential pore pressure dependence on water permeability. The trend is compared to the approximation curve of Eq. (7), which is based on the Bingham plastic flow into the assembly of a capillary tube.

\section{HESSD}

3, 1315-1338, 2006

Klinkenberg effect for gas permeability measurement

W. Tanikawa and

T. Shimamoto

Title Page

Abstract

Introduction

Conclusions

References

Tables

Figures

14

$\rightarrow 1$

4

Back

Close

Printer-friendly Version

Interactive Discussion 